\title{
ANALYSIS AND MODELING OF SOLAR EVAPORATOR-COLLECTOR
}

\author{
ZAKARIA MOHD. AMIN ${ }^{1}$, M.N.A. HAWLADER ${ }^{2}$ AND YE SHAOCHUN ${ }^{3}$

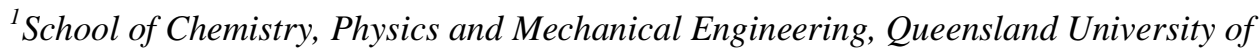 \\ Technology, Australia. \\ ${ }^{2}$ Department of Mechanical Engineering, Faculty of Engineering, International Islamic \\ University Malaysia, Jalan Gombak, 53100, Kuala Lumpur, Malaysia. \\ ${ }^{3}$ Department of Mechanical Engineering, National University of Singapore, 9 \\ Engineering Drive 1, Singapore 117576.
}

zakaria.amin@qut.edu.au,mehawlader@iium.edu.my,andye_shaochun@nmc.astar.edu.sg

(Received: August 10, 2015; Accepted: October 30, 2015; Published on-line: November 30, 2015)

\begin{abstract}
Solar energy is considered a sustainable resource that poses little to no harmful effects on the environment. The performance of a solar system depends to a great extent on the collector used for the conversion of solar radiant energy to thermal energy. A solar evaporator-collector (SEC) is basically an unglazed flat plate collector where refrigerants, such as R134a is used as the working fluid. As the operating temperature of the SEC is very low, it utilizes both solar irradiation and ambient energy leading to a much higher efficiency than the conventional collectors. This capability of SECs to utilize ambient energy also enables the system to operate at night. This type of collector can be locally made and is relatively much cheaper than the conventional collector. At the National University of Singapore, the evaporator-collector was integrated to a heat pump and the performance was investigated for several thermal applications: (i) water heating, (ii) drying and (iii) desalination. A 2-dimensional transient mathematical model of this system was developed and validated by experimental data. The present study provides a comprehensive study of performance.
\end{abstract}

ABSTRAK: Tenaga suria merupakan sumber lestari yang tidak memudaratkan alam sekitar. Keupayaan sistem ini bergantung sebahagian besarnya kepada kebolehan pengumpul untuk menukar tenaga suria kepada tenaga haba. Pengumpul penyejat suria (SEC) pada asasnya merupakan plat datar tanpa glasair di mana bahan penyejuk seperti R134a digunakan sebagai bendalir kerja. Memandangkan suhu kendalian SEC adalah amat rendah, ia boleh menggunakan penyinaran suria dan tenaga ambien agar memberikan efisiensi yang lebih tinggi daripada pengumpul konvensional. Keupayaan SEC dalam mempergunakan tenaga ambien membolehkan sistem ini beroperasi pada waktu malam. Pengumpul merupakan keluaran tempatan dan ianya lebih murah berbanding pengumpul lazim. Di Universiti Nasional Singapura, pengumpul penyejatnya diintegrasikan pada pam haba dan prestasinya dikaji untuk beberapa aplikasi terma: (i) pemanasan air, (ii) pengeringan dan (iii) penyahgaraman. Model matematik transien dua dimensi bagi sistem ini dikembang dan divalidasi berdasarkan data eksperimental. Selidikan terkini memberikan kajian prestasi yang menyeluruh.

KEYWORDS: heat pump; evaporator-collector.

\section{INTRODUCTION}

In view of the growing global energy needs and concern for environmental degradation, the possibility of running thermal systems using energy from the sun is 
receiving considerable attention in recent years. Solar energy is clean and is the most inexhaustible of all known energy sources. The low temperature thermal requirement of a heat pump makes it an excellent match for the use of solar energy. The combination of solar energy and heat pump system can bring about various thermal applications for domestic and industrial use, such as water heating, solar drying, space cooling, space heating, and refrigeration. Unlike thermosyphon solar water heaters, solar heat pump systems offer the opportunity to upgrade low-grade energy resources from the surroundings as well as solar energy and makes use of it for domestic and industrial applications [1].

The concept of direct expansion solar-assisted heat pump (DX-SAHP) was first proposed in an experimental study by Sporn and Ambrose [2]. They used double glazed collector which also act as evaporator for the heat pump with R-12 being the working fluid. They did not demonstrate the full potential of the concept due to a mismatched, oversized compressor. They also did experiments by removing the glazing and found that the removal did not affect the performance significantly. They found that removal of glazing or back insulation does not affect performance of two-phase flow solar collector significantly.

The collector operating temperature in a solar-assisted heat pump system can be lower than the ambient temperature. In this case, an un-glazed solar evaporator collector is used. The Simple structure of the un-glazed solar collector makes it an economical type of solar collector. However, its performance is highly dependent upon the environment, because its surface is exposed directly to the ambient. To improve the performance of unglazed solar collectors, a clear understanding of how the environment affects it is required.

An uninsulated, bare two-phase collector is firstly used in Franklin et al.'s [3] heat pump system. Chaturvedi et al.[4,5] found a variation of the evaporator temperature from $0^{\circ} \mathrm{C}$ to $10^{\circ} \mathrm{C}$ above the ambient temperature under favorable solar conditions. Many authors [6-8] reported that for ambient temperatures above $25^{\circ} \mathrm{C}$, the evaporator could be operated at an elevated temperature. Hawlader et al.[1] performed analytical and experimental studies on a solar assisted heat pump using unglazed, flat plate solar collectors, known as an evaporator-collector, using a steady-state one-dimensional mathematical model.

Two-phase flow in collectors was first considered by Sporn and Embrose [2]. They used a double glazed collector which also act as evaporator for the heat pump with R-12 being the working fluid. They did not demonstrate the full potential of the concept due to a mismatched, oversized compressor. They also did experiments by removing the glazing and found that the removal did not affect the performance significantly. They found that removal of glazing or back insulation does not significantly affect performance of the twophase flow solar collector.

Literature on two-phase collectors report that two models of calculating pressure drop are most widely used. These are known as the Martinelli Nelson's method for separated flows and Owen's homogeneous equilibrium model for misty or bubbly flow [9]. The homogeneous equilibrium model is the simplest method determining the pressure drop in two-phase flow and makes the basic assumption that the two-phases have the same velocity.

By adopting an equilibrium, homogeneous, two-phase model as mentioned above, Chaturvedi et al. [10] carried out preliminary theoretical performance studies concerning a solar-assisted heat pump that uses a bare collector as the evaporator. The analysis was 
subject to limitation of a constant temperature evaporator with no superheating or sub cooling. It is the first time wherethe single phase flat plate collector theory was extended to the two-phase regime.

The first comprehensive work about two-phase solar collector was carried out by Soin et al. [6]. The collector efficiency was found to increase linearly with the liquid level. The researchers investigated the thermal performance of a thermosyphon collector containing boiling acetone and petroleum ether, and developed a modified form of the HottelWhillier-Bliss equation (HWB)[11] to account for the fraction of liquid level in the collector with glazed. The steady-state thermal efficiency $\eta \mathrm{B}$ containing a modified heatremoval factor FR, in the HWB equation, for a two-phase solar collector is firstly defined by Al-Tamimi and Clark [7], accounting for the boiling and the sub-cooled portions of the collector. Researchers conducted a detailed study of boiling fluid solar collector in 1984 [8], in which an analytical model was developed to investigate of sub cooling the fluid entering the collector and the level of fluid in the collector on the collector efficiency. The term $Z^{*}$ was defined as reference to the fraction of the collector required to heat the fluid to its boiling temperature. Mainly based on the results of Al-Tamini and Clark's research, an ASHRAE 109-A test standard for two-phase solar collectors was established in 1984. This standard defined five sets of conditions for two-phase collector thermal efficiency [12].

Ahmed et al. [13] developed and defined a new generalized heat removal factor, Fs and a new overall thermal loss coefficient, UL for the two-phase flat-plate collector. Further modification on UL was also done in 1989 [14]. First steady-state system simulations made with TRNSYS was done by Freeman et al. [15]. The first thermodynamic model to analyze two-phase solar collector is developed by Chaturvedi et al. [4]. The equilibrium homogeneous theory is used to model the two-phase flow in solar collectors. O'Dell et al. developed a design method for heat pumps with refrigerant filled solar collectors [16]. The researchers obtained the heat gain at condenser and the COP as a function of evaporation temperature.

Numerical calculations of the collector efficiencies for a double-glazed two-phase flat-plate collector employing R-11 were carried out by Kishore et al. [17]. They firstly express the collector efficiency as a function of the saturation temperature and liquid level by combining their experimental data. Ramos et al.[18] also carried out theoretical investigation on two-phase collectors assuming laminar homogeneous flow and experimentally confirmed by them. Mathur et al. [19] developed a method calculating boiling heat transfer coefficient in a two-phase thermosyphon loop. The first detailed model for boiling solar collector using TRNSYS was developed by Price et al. [20]

All the modeling or analysis mentioned above assume a homogeneous two-phase flow. The first theoretical model concerning non-homogenous for two-phase flow thermosyphon in the collector and condenser was carried out by Yilmaz [21]. His results show that the homogenous model is not sufficient to describe the two-phase flow in the collector. Variation of the properties of the working fluid and water with temperature are taken into account. Considering the effect of long-wave radiation and wind speed, a modified form of the Hottel-Whillier-Bliss solar collector efficiency function for unglazed solar collector characterization is investigated by Morrison and Gilliaert [22].

Using the approach of element analyze of the steady one-dimensional two-phase energy conservation equations in finite, a mathematical model for natural circulation twophase solar collector with cover was developed by Radhwan et al. [23]. Torres Reyes et al. conducted the first exergy analysis on a solar-assisted heat pump with two-phase collector- 
evaporator [24]. They theoretically analyzed and experimentally confirmed that $80 \%$ irreversibilities in SAHP system occurs in collector-evaporator because a significant fraction of the total solar radiation absorbed is poorly employed. Similar investigation and results were obtained by Cervantes [25]. Most of the researches before 1999 were for steady-state in two-phase flow. Hussein firstly investigated theoretically and experimentally a two-phase closed thermosyphon flat plate solar collector under transient conditions [26]. He improved the modified the model in 2002 [27].

However no one has investigated the effect of the condensation phenomenon caused by high relative humidity $(\mathrm{RH})$ on the surface of un-glazed solar collectors. The effect of the condensation phenomenon on the collector performance was investigated in this study. A transient two-dimensional mathematical model of the evaporator-collector has been developed to predict temperature distribution and useful energy gain. A series of experiments were performed under the meteorological conditions of Singapore to validate the model.

\section{SYSTEM DESCRIPTION}

A solar assisted heat pump system for air-conditioning, water heating and drying is shown in Fig. 1. This system consists of five major components, namely the solar collector, evaporator, condenser (water cooled condenser and air cooled condenser), expansion valve, and compressor. Refrigerant R-134a was used as the working fluid due to environmental and thermodynamic considerations [4]. In the present study, two evaporators connected in parallel can increase the system coefficient of performance (COP) significantly. One of the evaporators performs as a solar collector, absorbing heat from solar radiation and ambient air; while another evaporator absorbs heat from a room for cooling purposes. The energy from these two heat sources, plus the electrical energy supplied to the compressor, is used for water heating and air heating for drying purposes.

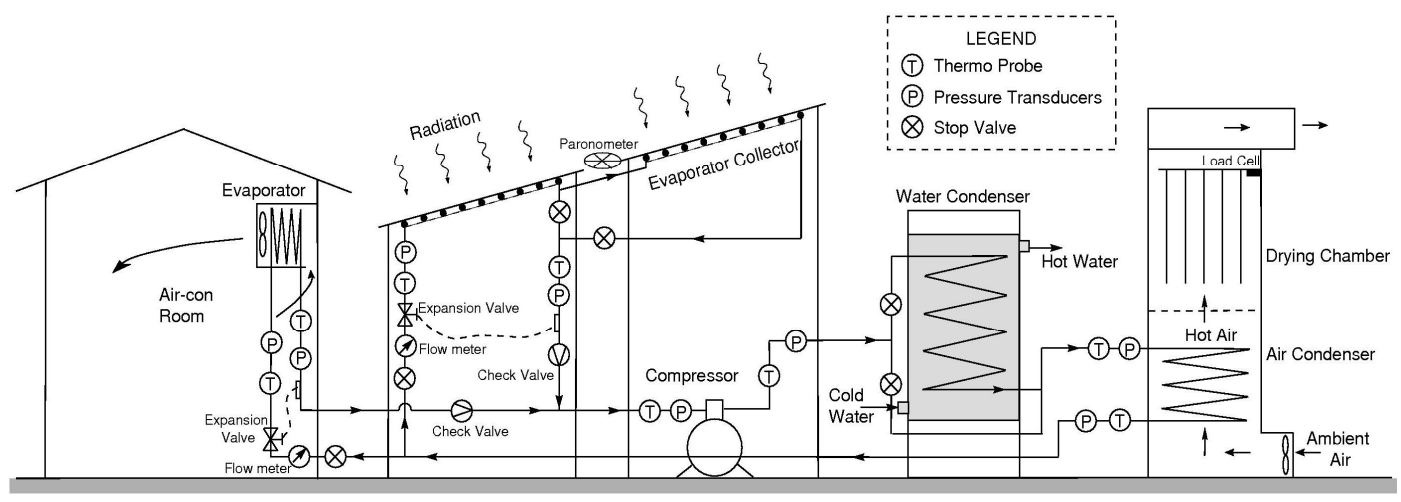

Fig. 1: Schematic overview of solar assisted heat pump air-conditioner, water heater and dryer.

The superheated refrigerant vapor leaving the compressor enters the water-cooled condenser and performs water heating. The refrigerant, a mixture of vapor and liquid, leaves the water-cooled condenser and enters an air-cooled condenser to ensure complete condensation of the refrigerant vapor. The hot air obtained from the air condenser is used for cloth drying purposes. Once complete condensation of the refrigerant vapor has taken place, the refrigerant path splits into two: one goes to evaporator-collector to absorb solar energy and the other goes to air-conditioned space to absorb thermal energy from the room 
to provide cooling. Superheated refrigerant vapor from the two evaporators mix together and enters into the compressor for next cycle.

Two evaporator-collectors each with an area of $1.5 \mathrm{~m}^{2}$, made of $1 \mathrm{~mm}$ copper plates were connected in series, as shown in Fig. 2. A $9.52 \mathrm{~mm}$ diameter copper tube was soldered at the back of each absorber plate in a serpentine configuration (Figure 2a). Adequate insulations were provided at the back of the collector but no glass cover was used on the top surface, i.e. the unglazed collector (Figure $2 b$ ). The collector surface was coated with a black paint with absorptivity of $90 \%$. There is a bypass line from the exit of the first evaporator-collector to the exit of the second evaporator-collector, which remains closed or open depending on the solar irradiation.

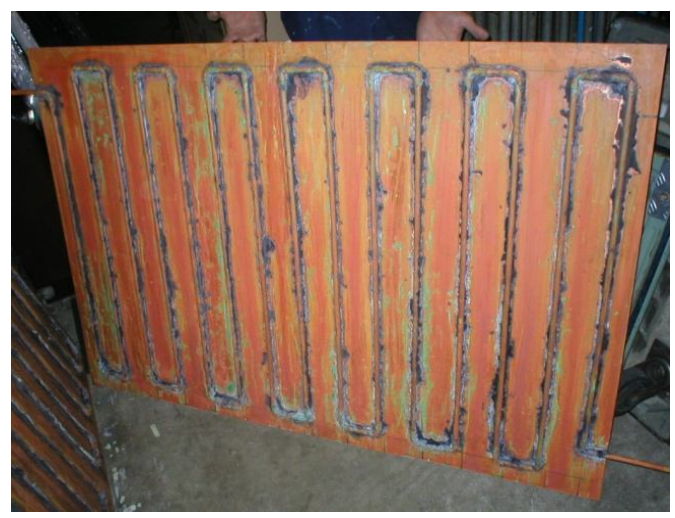

(a)

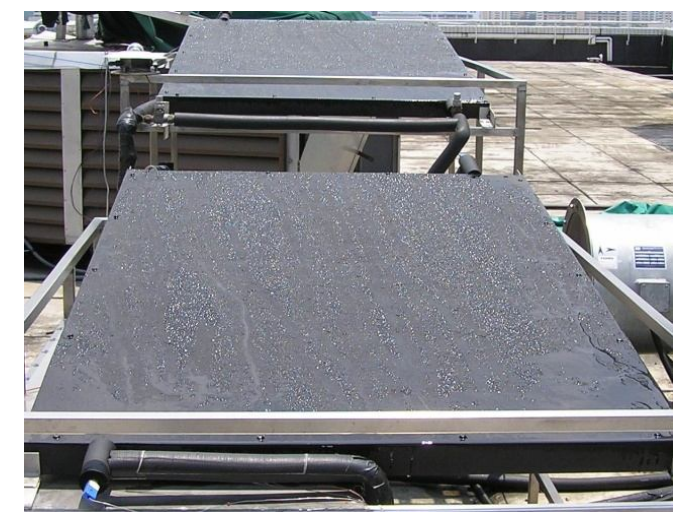

(b)

Fig. 2: Photograph of the un-glazed solar evaporator-collector.

\section{EVAPORATOR-COLLECTOR MODEL}

A transient two-dimensional mathematical model of the evaporator-collector has been developed to predict temperature distribution and useful energy gain.

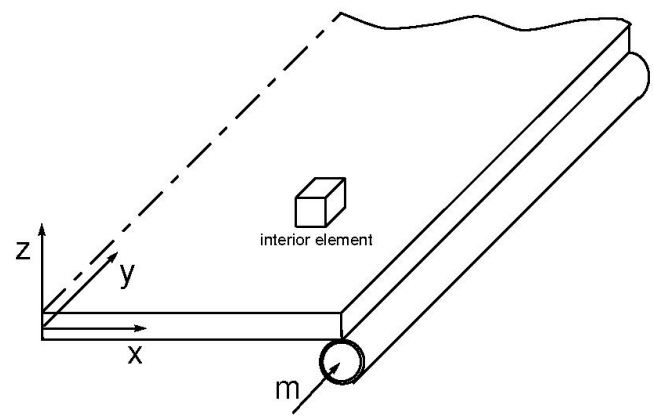

Fig 3: Geometry and coordinate system of the unglazed solar evaporator collector.

The function of an evaporator collector is to deliver the heat absorbed on the collector surface to the fluid in the tube. Because the copper plate is thin and its onductivity is high, the temperature variation in the $z$-direction can be considered as negligible. However, the heat transfer in the $y$-direction, as shown in Fig. 3, cannot be considered negligible because of the fact that the fluid temperature is not constant along the length of the tube. For this reason, the governing equation is derived to predict the performance of the evaporator collector by considering heat transfer in both $x$ and $y$ directions. 


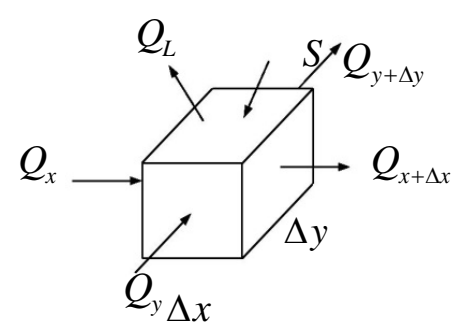

Fig. 4: Energy balance in a control volume in the interior area of collector.

An energy balance on the control volume is shown in Fig. 4 gives:

$$
Q_{x}+Q_{y}+Q_{u}-Q_{x+\Delta x}-Q_{y+\Delta y}=\rho c_{p}(\delta \Delta x \Delta y) \frac{\partial T}{\partial t}
$$

The term $\rho c_{p}(\delta \Delta x \Delta y) \frac{\partial T}{\partial t}$ represents the change of internal energy in the elemental control volume.

The terms $Q_{u}, Q_{x+\Delta x}$ and $Q_{y+\Delta y}$ are given by:

$$
\begin{aligned}
& Q_{u}=q_{u}(\Delta x \Delta y) ; \\
& Q_{x+\Delta x}=Q_{x}-k \delta \Delta x \Delta y \frac{\partial^{2} T}{\partial x^{2}} ; \\
& Q_{y+\Delta y}=Q_{y}-k \delta \Delta x \Delta y \frac{\partial^{2} T}{\partial y^{2}}
\end{aligned}
$$

Substituting these three terms into equation (1) gives the partial differential equation:

$$
\frac{q_{u}}{k \delta}+\frac{\partial^{2} T}{\partial x^{2}}+\frac{\partial^{2} T}{\partial y^{2}}=\frac{\rho c_{p}}{k} \frac{\partial T}{\partial t}
$$

Where $q_{u}=S-Q_{L}=S-U_{L}\left(T-T_{a}\right)$

This partial differential equation (2) requires one initial condition and four boundary conditions for its solution.

The initial condition is

At $t=0, T=T_{a}$ for all values of $x$ and $y$

3.1 The boundary at $y=0$ and $0<x<\frac{(W-D)}{2}$

Because the boundary at $y=0$ is exposed to the ambient, so

$$
\text { At } y=0, q_{y}=-U_{L}\left(T_{y 1}-T_{a}\right)
$$


Where $T_{y 1}=\left.T\right|_{y=0 \text { and } 0<x<\frac{(W-D)}{2}}$

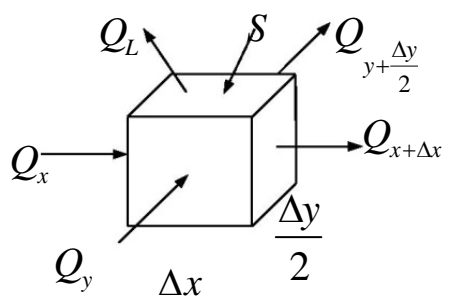

Fig. 5: Energy balance on the control volume at $y=0$.

At $y=0$, an energy balance on the control volume shown in Fig. 5 gives:

$$
Q_{x}+Q_{y}+Q_{u}-Q_{x+\Delta x}-Q_{y+\frac{\Delta y}{2}}=\rho c_{p}\left(\delta \Delta x \frac{\Delta y}{2}\right) \frac{\partial T_{y 1}}{\partial t}
$$

The terms $Q_{y+\frac{\Delta y}{2}}$ are given by:

$$
Q_{y+\frac{\Delta y}{2}}=-k \delta \Delta x \frac{\partial T_{y 1}}{\partial y}
$$

Substituting into equation (3):

$$
\frac{q_{u}}{k \delta}+\frac{\partial^{2} T_{y 1}}{\partial x^{2}}-\frac{2}{k \Delta y} U_{L}\left(T_{y 1}-T_{a}\right)+\frac{2}{\Delta y} \frac{\partial T_{y 1}}{\partial y}=\frac{\rho c_{p}}{k} \frac{\partial T_{y 1}}{\partial t}
$$

Similarly, the other three partial differential equations for boundaries are derived.

3.2 The boundary at $y=L$ and $0<x<\frac{(W-D)}{2}$

$$
\frac{q_{u}}{k \delta}+\frac{\partial^{2} T_{y 2}}{\partial x^{2}}-\frac{2}{k \Delta y} U_{L}\left(T_{y 2}-T_{a}\right)-\frac{2}{\Delta y} \frac{\partial T_{y 2}}{\partial y}=\frac{\rho c_{p}}{k} \frac{\partial T_{y 2}}{\partial t}
$$

3.3 The boundary at $x=0$ and $0<y<L$

$$
\frac{q_{u}}{k \delta}+\frac{\partial^{2} T_{x 1}}{\partial y^{2}}-\frac{2}{\Delta x} \frac{\partial T_{x 1}}{\partial x}=\frac{\rho c_{p}}{k} \frac{\partial T_{x 1}}{\partial t}
$$

3.4 The boundary at $x=\frac{(W-D)}{2}$ and $0<y<L$

$$
\frac{q_{u}}{k \delta}-\frac{2}{D} \frac{\partial T_{x 2}}{\partial x}-\frac{\left(T_{x 2}-T_{f}\right)}{k \delta D\left(\frac{1}{h_{f i} \pi D_{i}}+\frac{1}{C_{b}}\right)}=\frac{\rho c_{p}}{k} \frac{\partial T_{x 2}}{\partial t}
$$


Where $T_{y 2}=\left.T\right|_{y=L \text { and } 0<x<\frac{(W-D)}{2}} \quad ; \quad T_{x 1}=\left.T\right|_{x=0 \text { and } 0<y<L} \quad ; \quad T_{x 2}=\left.T\right|_{x=\frac{(W-D)}{2} \text { and } 0<y<L}$

The four corner points are special conditions of the boundary conditions. The PDE for them are derived by the same energy balance method as for the boundary conditions.

\subsection{The Overall Heat Transfer Coefficient UL}

As shown in Fig. 6 the plate on the tube has five parts of heat gain.

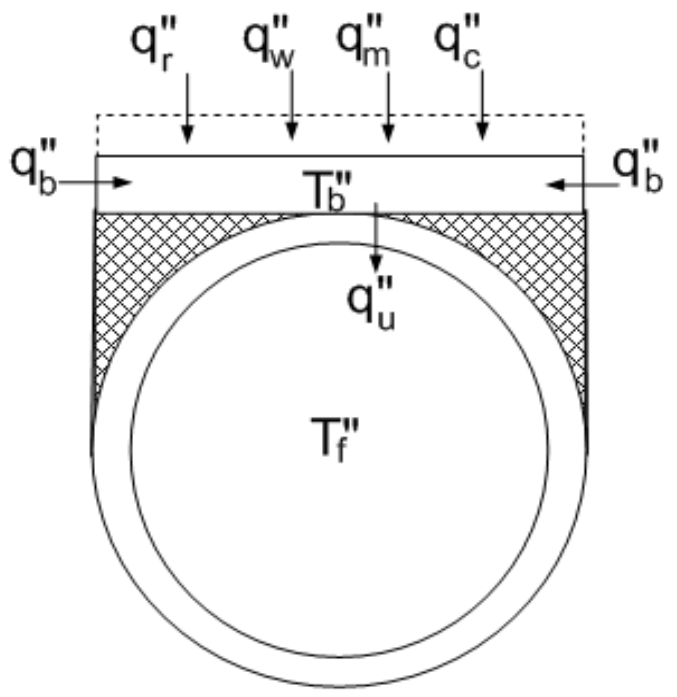

Fig. 6: The cross-section of plate and the tube.

The energy released to the fluid is $q_{u}^{\prime \prime}$, and

$$
q_{u}^{\prime \prime}=q_{b}^{\prime \prime}+\left[q_{r}^{\prime \prime}+q_{w}^{\prime \prime}+q_{m}^{\prime \prime}+q_{c}^{\prime \prime}\right]
$$

Where, $q_{u}^{\prime \prime}$ is decided by the flow condition inside the tube.

$$
q_{u}^{\prime \prime}=\frac{\left(T_{b}-T_{f}\right)}{\left[\frac{1}{h_{f i} \pi D_{i}}+\frac{1}{C_{b}}\right]}
$$

Where $h_{f i}=\frac{0.0082 k_{f}}{D_{i}}\left\{\frac{\left[\operatorname{Re}_{D i}{ }^{2} J(1-x)\right] h_{f g}}{L}\right\}$

The effect of condensation is built into the overall heat transfer coefficient, which can be separated into three parts: wind heat transfer coefficient $h_{w}$, the radiation heat transfer coefficient $h_{r}$ and the condensation heat transfer coefficient $h_{\text {cond }}$

$$
U_{l}=h_{w}+h_{r}+h_{\text {cond }}
$$


Where:

$$
\begin{aligned}
& h_{w}=2.8+3 V_{a} \\
& h_{r}=\sigma \varepsilon_{p} \frac{\left(T_{p}^{4}-T_{s k y}^{4}\right)}{\left(T_{p}-T_{a}\right)}
\end{aligned}
$$

An empirical equation has been developed by Swinbank in [8], which relates, $T_{\text {sky }}$ to ambient temperature, $T_{a}$, as shown below:

$$
T_{s k y}^{4}=0.0552 T_{a}^{1.5}
$$

where, they are both in Kelvin.

For the condensation heat transfer coefficient $h_{c o n d}$, if $T_{p}$ is greater than $T_{\text {dew }}$, condensation will not occur, then $\mathrm{h}_{\text {cond }}=0$

If $T_{p}<T_{d e w}$ :

$$
h_{\text {cond }}=1.13 R H_{a}\left[\frac{g \rho_{w}^{2} k_{w}^{3} \cos \phi h_{f g}}{\mu_{w} L_{p}\left(T_{a}-T_{p}\right)}\right]^{1 / 4}
$$

Lockhart-Martinelli Parameter $\mathrm{X}_{\mathrm{tt}}[10]$ is used for two-phase flow

$$
X_{t t}=(1-x)^{0.9}\left(\frac{\rho_{l}}{\rho_{v}}\right)^{-0.5}\left(\frac{\mu_{l}}{\mu_{v}}\right)^{0.1}
$$

The two-phase heat transfer coefficient is

$$
h_{t p}=2.44 h_{l} X_{t t}^{-0.863}
$$

\section{RESULTS AND DISCUSSION}

Results were obtained for both simulation and experimental data. Meteorological data for a typical day in Singapore is shown in Fig. 7 and 8. Singapore is located at a latitude of $1^{\circ} 22^{\prime} \mathrm{N}$ and longitude of $103^{\circ} 55^{\prime}$. There is hardly any seasonal variation of the meteorological conditions in Singapore. The typical daily variations are shown in Fig. 7 and Fig. 8. 


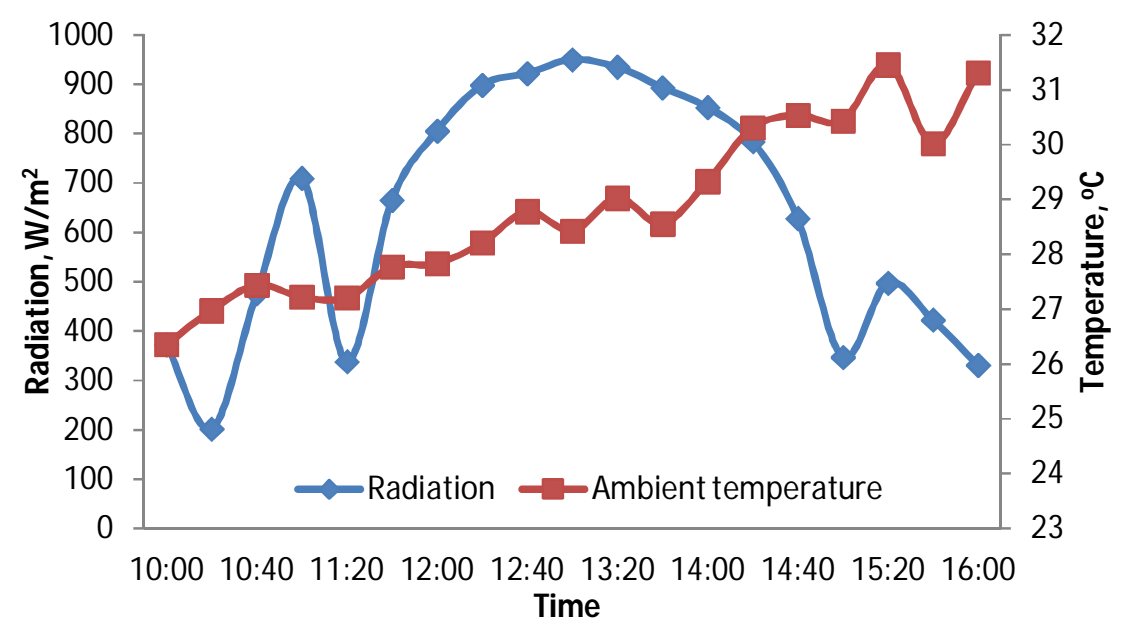

Fig. 7: Variation of solar radiation and ambient temperature with time.

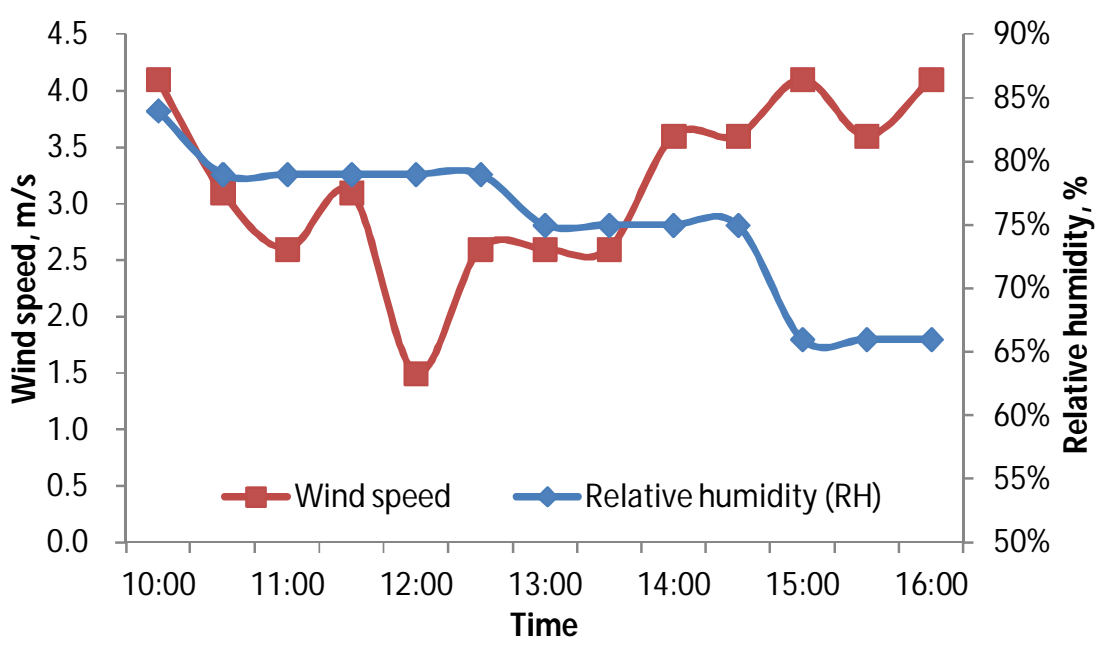

Fig. 8: Variation of relative humidity and wind speed with time.

As seen from Fig. 7 and Fig. 8, both solar radiation (global) and wind speed vary in an unpredictable manner with time. Solar radiation is around $1000 \mathrm{~W} / \mathrm{m}^{2}$ at noon. The ambient temperature reaches the highest point at around $2 \mathrm{pm}$ and relative humidity rises to as high as $86 \%$ in the morning and continuously decreases. The average and maximum wind speed are 3.0 and 4.1 respectively, indicating that wind in Singapore is not strong.

In Fig. 9, the measured and predicted useful energy gain, $\mathrm{Q}_{\mathrm{u}}$, by the unglazed solar evaporator-collector and solar irradiation are plotted against time. Useful energy gain is a combination of energy gain from irradiation and the ambient. The contribution of these two parts is obtain by simulation analysis and presented in Fig. 9.

As seen from Fig. 9, the energy from radiation Qu_radiation is highly depended on the radiation level. In contrast to $\mathrm{Qu}$ _radiation, energy absorbed from the ambient, $\mathrm{Qu}$ _ambient, is relative constant. It decreased with the rise of radiation due to the fact that the temperature difference between ambient and collector dropped caused by the increase of plate surface temperature as a result of the rise of radiation. 


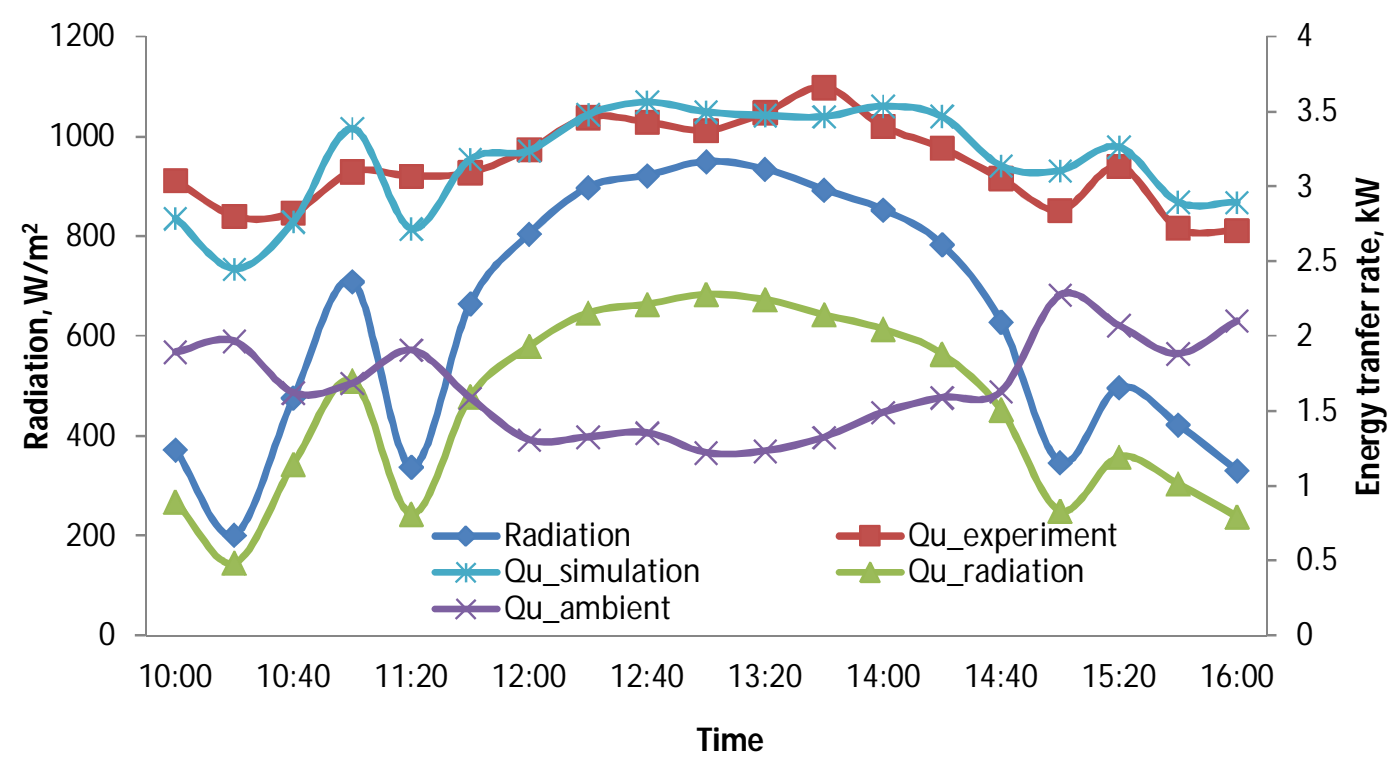

Fig. 9: Comparison of predicted and measured useful energy gain and solar radiation with time.

It shows that predicted $\mathrm{Q}_{\mathrm{u}}$ has a reasonably good agreement with experimental values in full mode operation. Both of them varied in the range from $2.5 \mathrm{~kW}$ to $3.7 \mathrm{~kW}$ with the change of radiation. Unlike the normal solar collector, the amplitude of the fluctuation of useful energy gain by this evaporator-collector is less than that of solar radiation. This can be attributed to the fact that it not only absorbs energy from radiation but also from ambient due to its low surface temperature, leading to a relatively steady useful energy gain.

\subsection{Comparison of 1-D and 2-D Models}

In the current study, a two-dimensional (2-D) mathematical model of the evaporatorcollector has been developed. In this model, the plate heat transfer in both the x-direction (vertical to the tube) and $y$-direction (parallel to the tube) are taken into account. However, in the conventional one-dimensional (1-D) model, which is simpler than the 2-D mode, the heat transfer inside the plate in $y$-direction is neglected.

The comparison of simulation results using both the 1-D and 2-D mathematical models of the evaporator-collector is presented in this section. Results of different parameters are presented against solar radiation ranged from $100 \mathrm{~W} / \mathrm{m}^{2}$ to $1000 \mathrm{~W} / \mathrm{m}^{2}$. The other conditions are chosen as follows:

Ambient temperature $=30^{\circ} \mathrm{C}$, refrigerant mass flow rate $=0.012 \mathrm{~kg} / \mathrm{s}$, Wind Speed $=3.5$ $\mathrm{m} / \mathrm{sec}$, Relative humidity $=70 \%$ and refrigerant condensed temperature $=35^{\circ} \mathrm{C}$.

Before the comparison, the effect of radiation on the length of two-phase flow is presented in Fig. 10. It should be noted that the total tube length is $30 \mathrm{~m}$. Simulation results of useful energy gain and collector efficiency from 1-D and 2-D model are plotted against solar radiation in Fig. 11. As seen from the figure, simulation results using 1-D and 2-D mathematical model of the evaporator-collector are very close, especially in low radiation condition. The average difference is only $3 \%$ of the $2-\mathrm{D}$ result. It can be explained by the fact that the heat transfer in $y$ direction is almost 0 in two-phase flow region, caused by the constant refrigerant temperature in the two-phase region. 
The difference between the 1-D and 2-D mathematical model results is mainly due the heat transfer inside the plate in $y$-direction, caused by the rapid change of refrigerant temperature in single-phase region. This is neglected in the 1-D model. Therefore the difference between the results between the 1-D and 2-D model increases with the rise of radiation due to the rise of length of single-phase flow. As shown in Fig. 11 difference, which is $4.3 \%$ of $2-D$ result, occurs at radiation $\mathrm{I}=1000 \mathrm{~W} / \mathrm{m}^{2}$

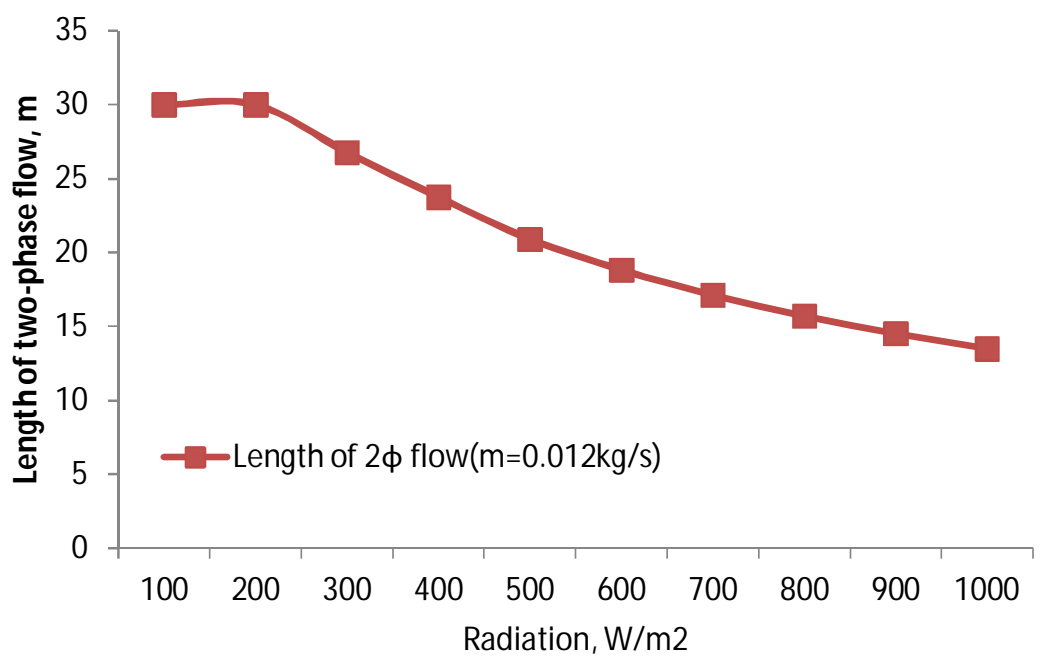

Fig. 10: Variation of length of two-phase flow with solar radiation.

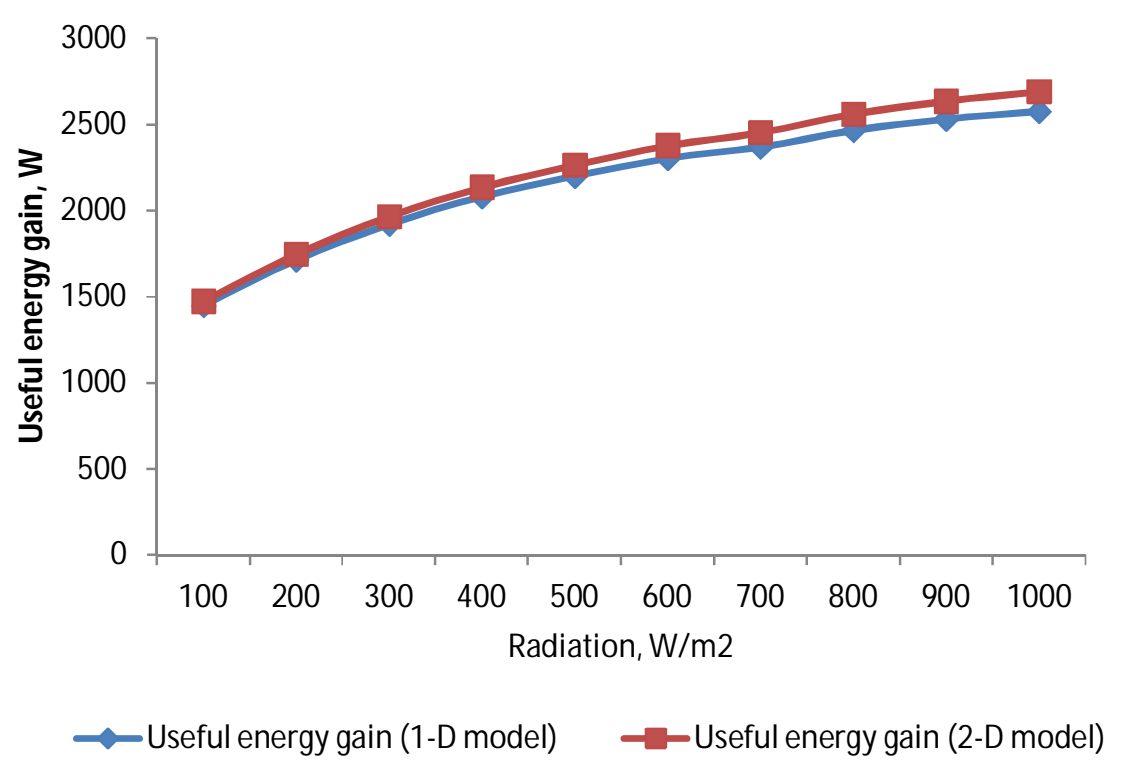

Fig. 11: Comparison of useful energy gain and collector efficiencies for 1-D simulation model and 2-D simulation model.

\subsection{Parametric Study}

The condensed refrigerant after the expansion valve entered the unglazed evaporatorcollector in two-phase flow. The vapor quality is gradually increased to 1 and the flow becomes a super heated single-phase flow. The analysis against tube length in different 
solar radiation conditions is presented in this section. The other conditions are chosen as follows:

Ambient Temperature $=30^{\circ} \mathrm{C}$, Wind Speed $=3.5 \mathrm{~m} / \mathrm{sec}$, Relative humidity $=70 \%$, Mass flow rate $=0.012 \mathrm{~kg} / \mathrm{s}$ and Condensed Temperature $=35^{\circ} \mathrm{C}$.

Variation of vapor quality with tube length in different solar radiation is presented in Fig. 12.

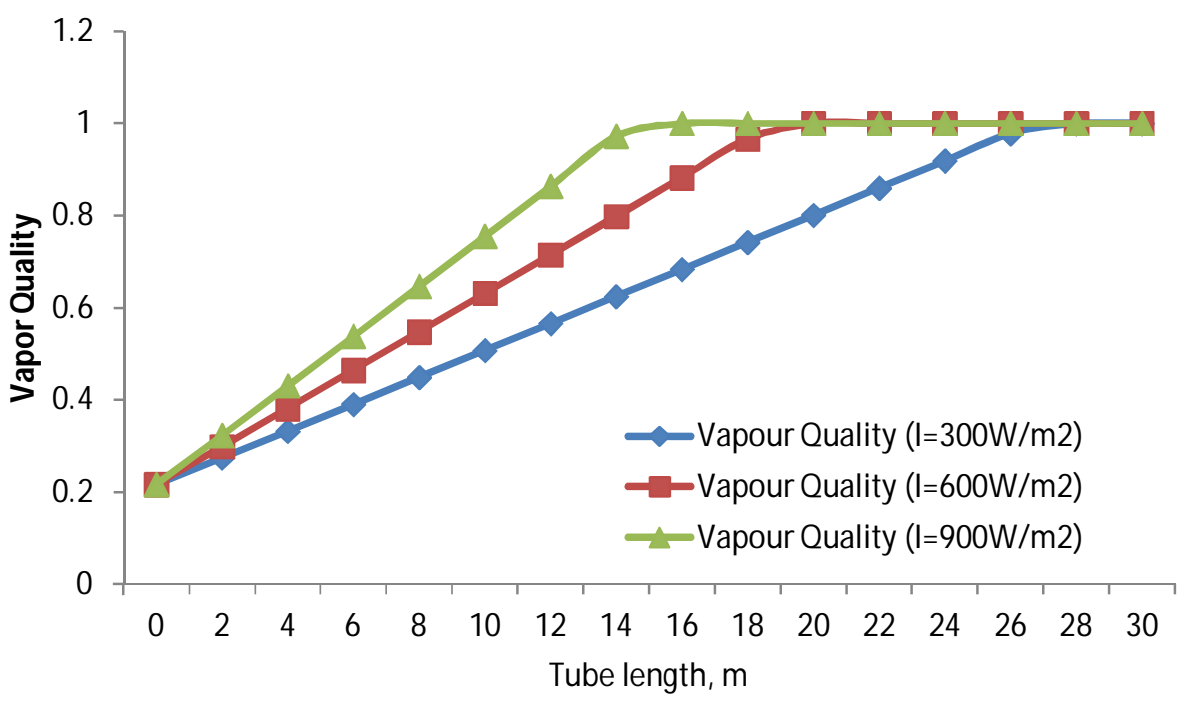

Fig. 12: Variation of vapor quality with tube length in different solar radiation.

The point at where vapor quality becomes 1 is the point of the end of the two-phase flow. As seen from the figure, the increasing rate of vapor quality in the tube is greatly affected by the level of radiation. It is observed that the higher the solar radiation, the shorter the length of two-phase flow. Variation of heat transfer coefficient inside the tube with tube length in different solar radiation is presented in Fig. 13. As can be observed in the figure, the heat transfer coefficient increase with the rise of vapor quality in two-phase flow and dramatically dropped in single-phase region. Figure 14 shows the accumulated useful energy gain with tube length in different solar radiation.

As shown in the figure, the increasing rate of useful energy gain dramatically dropped after the two-phase flow become single-phase, as a result of the fall of heat transfer coefficient inside the tube. It means the useful energy gain per unit length in two-phase region is much higher than that in single-phase region.

For the total tube length, higher the solar radiation, higher is the total useful energy gain. It is also noted that the difference of useful energy gain between radiation at 600 $\mathrm{W} / \mathrm{m}^{2}$ and $900 \mathrm{~W} / \mathrm{m}^{2}$ is almost constant in the tube length for $20 \mathrm{~m} \sim 30 \mathrm{~m}$. It can be attributed to the fact that both of them are in single-phase status in this region. It indicated that, the radiation effect on evaporator-collector performance of single phase flow is much less than that in two-phase flow. 


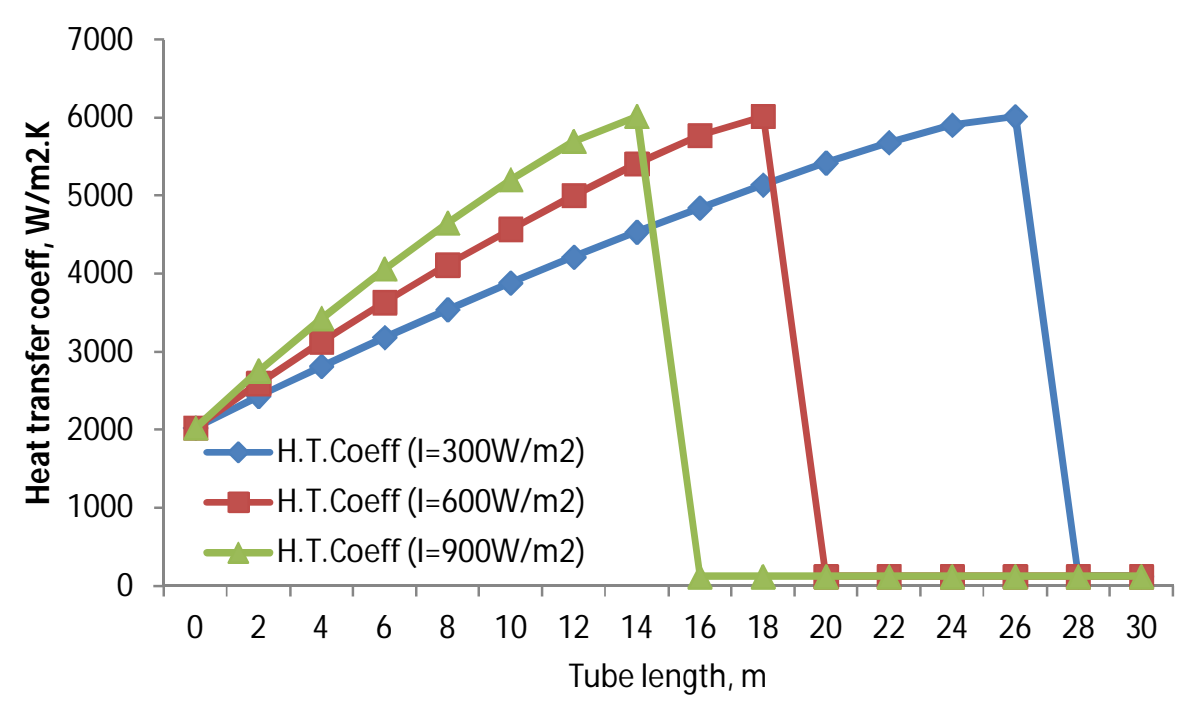

Fig. 13: Variation of heat transfer co-efficient inside the tube with tube length and different solar radiation.

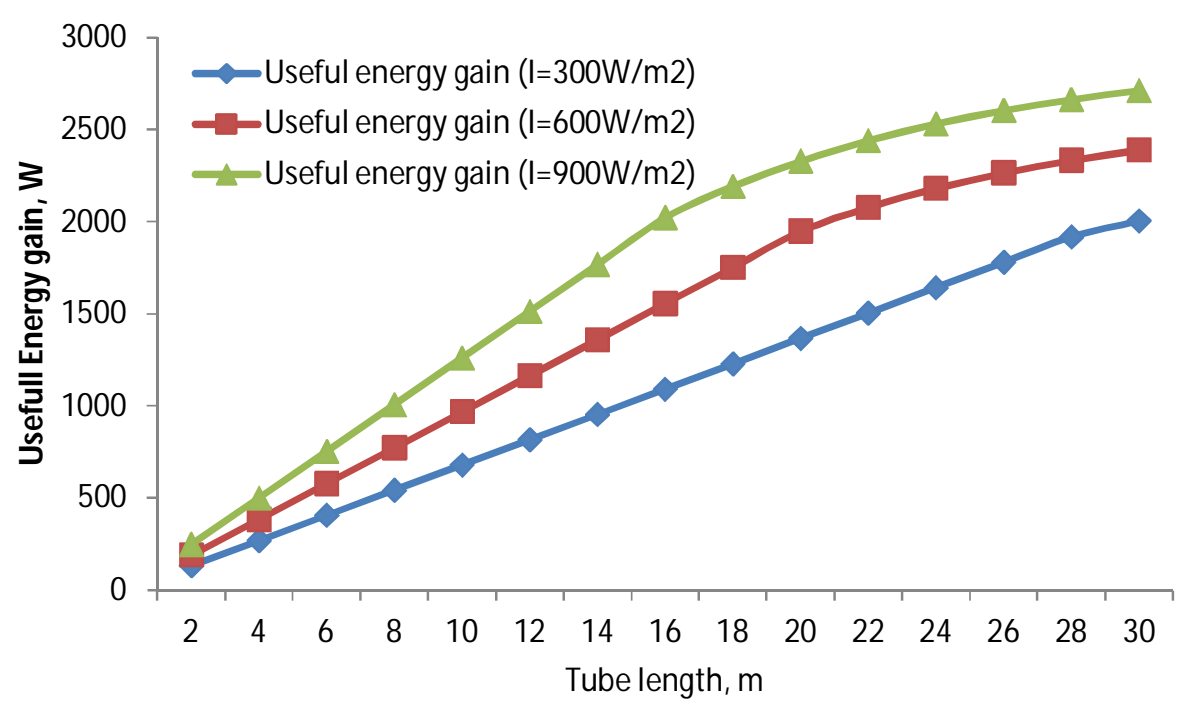

Fig. 14: Variation of useful energy gain with tube length and different solar radiation.

Useful energy gain is the combination of energy gain from radiation and ambient. The energy gain from radiation and ambient with tube length in different solar radiation is presented in Fig. 15. As shown in the figure, in the two-phase flow region, the solar radiation affects the collector useful energy gain mainly by affecting the useful energy gain from radiation. In the two-phase flow region, the higher the solar radiation, the higher is the $\mathrm{Qu} \_$rad. However, the variation of useful energy gain from ambient, $Q u \_a m b$, is almost same in two-phase flow for three radiation conditions. 


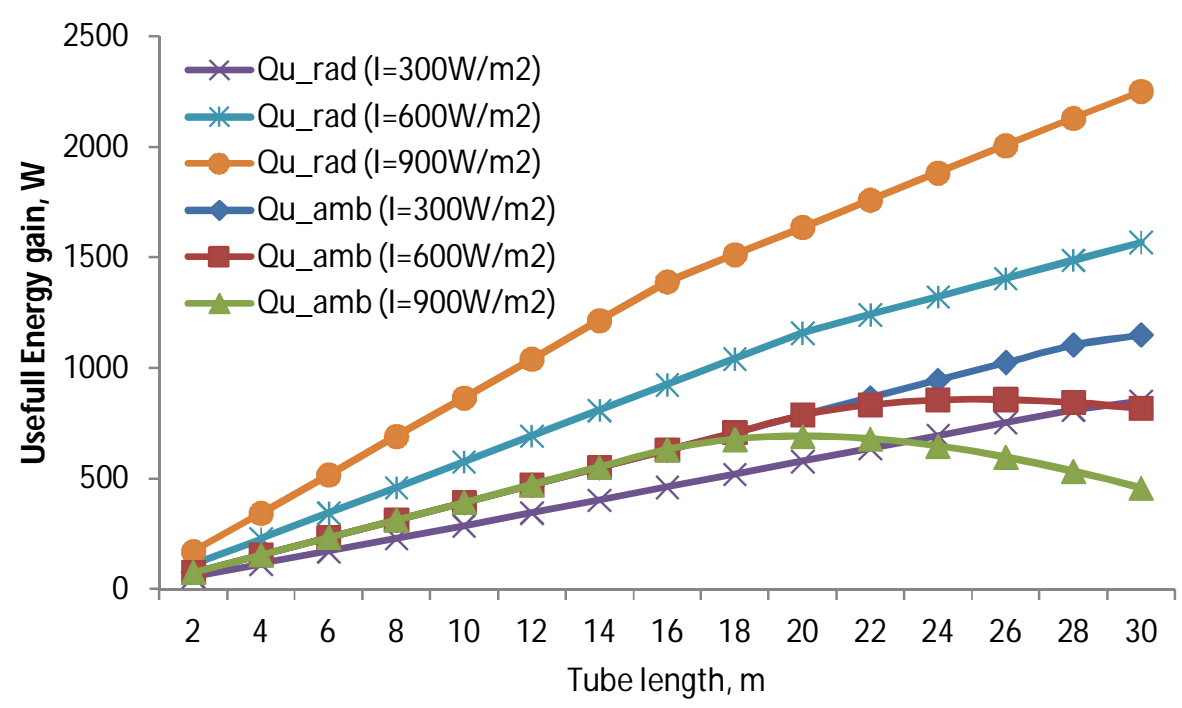

Fig. 15: Variation of energy gain from radiation and ambient with tube length in different solar radiation.

The increasing rate of $\mathrm{Qu}$ _rad drops slightly in single phase flow due to the drop of heat transfer coefficient inside the tube. In contrast, the increasing rate of useful energy gain from ambient dropped remarkably and even become negative in single phase flow. It is due to the rise of plate temperature caused by the increase of refrigerant temperature in single phase flow. Figure 15 indicates that both $\mathrm{Qu}$ _rad per unit length and $\mathrm{Qu}$ _amb per unit length in two-phase region are higher than those in single phase region. Variation of collector plate surface temperature with tube length for different solar radiation conditions is presented in Fig. 16.

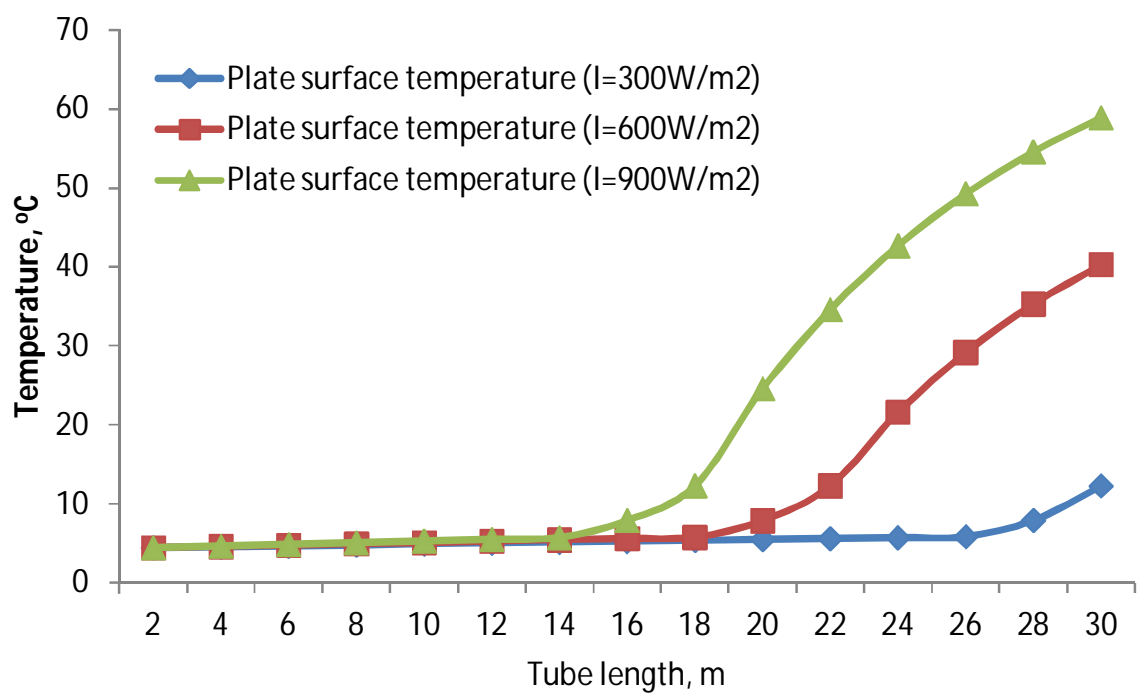

Fig.16: Variation of collector plate surface temperature with tube length in different solar radiation.

The plate surface in two-phase flow is not much different for the three radiation conditions. It is mainly determined and close to the refrigerant temperature, which is 
almost constant in two-phase flow. However, the plate surface temperature increases is caused by the increase of refrigerant temperature in single phase flow.

The analysis against tube length indicated that the evaporator-collector performance in two-phase region and single phase region are quite different. Hence it is important to identify the two-phase flow length in future studies.

\section{CONCLUSIONS}

An integrated solar heat pump system was designed and built to evaluate its performance under the meteorological conditions of Singapore. The performance of a twophase unglazed solar evaporator-collector in a solar-assisted heat pump system is investigated. A transient two-dimensional mathematical model of the evaporator-collector has been developed to predict temperature distribution and useful energy gain. To validate the model, experiments were conducted under the meteorological conditions of Singapore.

It has been determined that the thermal performance of the two-phase unglazed solar evaporator- collector is affected significantly by refrigerant mass flow rate, solar irradiation, collector area, ambient temperature and relative humidity. Both experimental and analytical results show that for the two-phase unglazed solar evaporator-collector, instead of losing energy to the ambient, energy is gained by a significant amount due to low operating temperature of the collector. With this evaporator-collector, the system can be operated even in the absence of solar radiation at night.

Analytical results show that both the heat transfer coefficient and energy gain in twophase region of collector are much higher than those in the single phase (saturated vapor) region. The length of the two-phase region also increases while the refrigerant mass flow rate declines. This analysis shows that the two-phase unglazed solar evaporator-collector has good potential for application in the tropics.

\section{REFERENCES}

[1] Hawlader MNA, Chou SK, Ullah MZ. (2001) The performance of a solar assisted heat pump water heating system. Applied Thermal Engineering, 21(10):1049-1065.

[2] Sporn P, Ambrose ER. (1995) The heat pump and solar energy, in World symposium on applied solar energy. Phoenix, Arizona, USA.

[3] Franklin JL, Saaski EW, Yamgiwa A. (1977) A high efficiency, direct expansion solar plane, in Flat-Plate Solar Collector Conference. Orlando, Florida, USA.

[4] Chaturvedi SK, Chiang YF, Roberts As. (1982) Analysis of two-phase flow collectors with applications to heat pumps. ASME Transaction Journal of Solar Energy Engineering, 104(4):358-365.

[5] Chaturvedi SK, Mei VC. (1979) Thermal performance of SAHP system with combined collector/evaporator, in AIAA Terrestrial Energy Systems Conference. Orlando, Florida, USA.

[6] Soin RS, et al. (1979) Performance of flat plate solar collector with fluid undergoing phase change. Solar Energy, 23(1):69-73.

[7] Al-Tamimi AI, Clark JA. (1983) Thermal analysis of a solar collector containing a boiling fluid, in American Solar Energy Society Annual Meeting. Minneapolis, USA.

[8] Al-Tamimi AI, Clark JA. (1984) Thermal performance of a solar collector containing a boiling fluid (R-11). ASHRAE Transactions, 90:1B:681-693.

[9] Tong LS. (1965) Boiling heat transfer and two-phase flow. John Wiley and Sons Inc. New York. 
[10] Chaturvedi SK, Roberts AS, Mei VC. (1979) Solar collector as heat pump evaporator, in $14^{\text {th }}$ Intersociety Energy Conversion Engineering Conference. Boston, USA. American Chemical Society, Proceedings 1, 99-104.

[11] Hottel H, Whillier A. (1955) Evaluation of flat-plate solar collector performance, in Trans. Conf. Use of Solar Energy, 12 (3) (Thermal Processes) Part 2.

[12] Spears RP, Waldin VH. (1984) ASHRAE 109-A test standard for two-phase solar collectors. ASHRAE Transcations, 90:697-706.

[13] El-Assy AY, Clark JA. (1988) Thermal analysis of a flat-plate collector in multiphase flows, including superheat. Solar Energy, 40(4):345-361.

[14] El-Assy AY, Clark JA. (1989) Thermal analysis of a flat-plate boiling collector having subcooled inlet and saturated exit states. Solar Energy, 42(2):121-132.

[15] Freeman TL, Mitchell JW, Audit TE. (1979) Performance of combined solar-heat pump systems. Solar Energy, 22(2):125-135.

[16] O'Dell MP, Mitchell JW, Beckman WA. (1984) Design method and performance of heat pumps with refrigerant filled solar collectors. Journal of Solar Energy Engineering, 106(2):159-164.

[17] Kishore VVN, Gandhi MR, Rao KS. (1984) Analysis of flat-plate collectors charged with phase-changing fluids. Applied Energy, 17(2):133-149.

[18] Ramos E, Sen M, Treviño C. (1985) A steady-state analysis for variable area one- and twophase thermosyphon loops. International Journal of Heat and Mass Transfer, 28(9):17111719.

[19] Mathur GD, McDonald TW. (1986) Simulation program for a two-phase thermosyphon loop heat exchanger. ASHRAE Transcations, 92:473-485.

[20] Price HW, Klein SA, Beckman WA. (1986) Analysis of boiling flat-plate collectors. Journal Solar Energy Engineering, 108(2):150-158.

[21] Yilmaz T. (1991) Computer simulation of two-phase flow thermosyphon solar water heating system. Energy Conversion and Management, 32(2):133-144.

[22] Morrison GL, Gilliaert D. (1992) Unglazed solar collector performance characteristics. Journal of Solar Energy Engineering, 114(3):194-200.

[23] Radhwan AM, Zaki GM. (1993) Analysis of refrigerant-charged s olar collectors with phase change. Heat Recovery Systems and CHP, 13(5):429-439.

[24] Torres Reyes E, Picon Nunez M, Cervantes JG. (1998) Exergy analysis and optimization of a solar-assisted heat pump. Energy, 23(4):337-344.

[25] Cervantes JG, Torres-Reyes E. (2002) Experiments on a solar-assisted heat pump and an exergy analysis of the system. Applied Thermal Engineering, 22(12):1289-1297.

[26] Hussein HMS, Mohamad MA, El-Asfouri AS. (1999) Transient investigation of a thermosyphon flat-plate solar collector. Applied Thermal Engineering, 19(7):789-800.

[27] Hussein HMS. (2002) Transient investigation of a two-phase closed thermosyphon flat plate solar water heater. Energy Conversion and Management, 43(18):2479-2492. 